\title{
Geopolitics, Global Governance and Crisis Narratives
}

\author{
Anna Schmidt with Paz Arancibia, Rakhil Kahlon, Nobuhiro Komoto, \\ John Myers, Mary Munyi, Tonaina Ngororano, George Omondi, \\ Prabal Sepaha, Kim Yeojeong
}

\begin{abstract}
The financial crisis demonstrated a new quality of interconnected vulnerabilities across the globe. Yet, increased interdependence may lead to increased friction rather than common problem-solving or a shared outlook. This article is concerned with the prospects for future reform of global economic governance, taking as a starting point the apparent shift from the G8 to the $G 20$ as the focal forum for reform. We show that (1) the crisis both reflects and propels important geopolitical change and that (2) interpretations of the crisis differ widely, leading to diverging ideas of different actors about each other and about future reforms. We then consider some implications, notably with regard to the utility of summitlevel diplomacy and the transfer of responsibilities to controversial institutions, all within an environment marked by ongoing uncertainty.
\end{abstract}

\begin{abstract}
1 Introduction
The most visible reaction of policymakers to the financial crisis was a focus on containment and immediate protection. Yet alongside this, a second focus has been on efforts at long-term protection, including on how to restructure and to reform, so that financial crises, which have arguably grown in frequency and intensity over the past 40 years, can be prevented or better contained and managed.
\end{abstract}

This second strand of policymaking involves structural decisions in which seemingly technical considerations about tools and mechanisms are particularly closely tied to political institutions and the nature of shifting global interdependence and power. Here the new circumstances have revived old agendas; developing countries in particular have long been concerned with the need to reform global economic governance, notably the international financial institutions (IFIs) and the G8 club regime, if only to better reflect the fundamental changes in the importance and interests of developing countries in the last 50 years. Indeed, in one notable shift, the crisis brought about the high-profile outreach to the G20.
This changed constitution of the focal leadership aimed to reinforce the legitimacy of any new arrangements. It also provides an important starting point for thinking about the wider reform of global (economic) governance: this article is a contribution to this thought process. Our starting point is potentially obvious: expanding representation is not a panacea for more just or more effective reform. Beyond this, and to shed light on the dynamics of reform, we make a series of interlinked arguments: (1) the crisis reflects and propels geopolitical changes; (2) it is interpreted differently by different actors; (3) both factors are consequential for institutional reform and the capacity for concerted action, whether in the G20 setting or elsewhere.

The above arguments also provide the basic structure of this article. The first section briefly surveys shifts in power, both geopolitical and (with respect to the G20) institutional. The second section introduces the element of perception by distinguishing different ways to 'frame' or characterise the current crisis. It first outlines these distinct frames and then reports on relevant elite-level or media debates within selected 
members of the G20. The final section addresses some of the implications for approaches to structural reform by reviewing the results of the London Summit of April 2009 (G20 2009). We conclude with observations regarding future challenges and the significance of summit-level diplomacy.

\section{What world are we in? 2.1 Geopolitics}

At the time of writing, the crisis is still unfolding, with experts continuously readjusting their interpretations and estimates of both its trajectory and speed (see IMF 2009; HM Treasury 2009). Yet some things are clearer than others: originating in the developed world it demonstrated a fundamentally new quality of global interdependence and interconnected vulnerabilities across the globe. Its speed and trajectory confirmed some pre-existing trends and challenged others. Three points are especially noteworthy: the limits to decoupling, uncertainties about macroeconomic imbalances, and the return of governments in economic relations.

\section{The reach of global interdependence}

The crisis debunked popular theories of 'soft decoupling,' or the relative independence of economic cycles in different parts of the world. All were affected, and to often unexpected degrees. Spread occurred for instance through the prominent role of mobile or tradable financial assets such as portfolio equity and Foreign Direct Investment. Emerging markets have proved extremely vulnerable through financing gaps and the retreat of investment, but also through the collapse of their export markets. At the same time country-level effects varied widely, depending on trade structure, relative exposure of a country's financial system, dependence on flows of remittances or tourism, size of private sector financing and its investment profile, among others.

\section{Macroeconomic imbalances}

The crisis also revived long-standing concerns about macroeconomic imbalances and the role of the dollar as the international reserve currency. In the short run, the dollar seemed to reassert itself as the world's reserve currency, leading to large scale devaluations and concomitant problems in much of the rest of the world. However, doubts persist over its long-term position. Indeed, the future US international investment position is likely to be affected at the same time as massive US government spending, which will require ever more significant capital inflows. Yet arguably, countries holding large foreign reserves that pay low interest rates in a currency likely to depreciate have large incentives to diversify. China's proposal for an international reserve currency seems to respond to such concerns. More generally, new debtors in a world where government debt is rising will have various and increasing degrees of power over economic restructuring.

\section{The role of governments}

Paradoxically, while demonstrating the true scale and impact of international economic globalisation, the crisis seemingly reasserted the role of governments and national economies. In the developed world, this is evident in the role of governments in international finance, be it through direct nationalisation, more indirect bail-outs or increased regulation. Post-crisis banks now have ever closer links to governments; and central banks are ready to increase their responsibilities beyond price stability. At the same time, the restructuring of financial institutions is a matter of international politics between governments. From Detroit to Paris, governments moved to protect or restructure key national industries, or reinforced each other when calling for a clamp down on tax havens.

The shifting balance between private and public money also affects the role of aid: with the exception of sub-Saharan Africa, private capital flows to the developing world had become a key source of finance. These are likely to be radically reduced, increasing the relative importance of bilateral and multilateral Official Development Assistance (ODA). So far, Chinese aid is unlikely to decline with the financial crisis (Cook 2009), so any diminishing Organisation for Economic Cooperation and Development (OECD) aid would also reduce these countries' influence or ability to shape aid modalities. Multilateral ODA will increase the role of IFIs, whose resources may increasingly be leveraged through Asian Foreign Exchange reserves. Finally, at the time of writing, the decline in commodity prices suggests changing room for manoeuvre for resource-rich countries, including for instance Russia and Venezuela.

The above observations highlight that the relative positions of current political actors are 
shifting. Where this is the case, discussions about specific policies or measures are directly linked to those relating to broader organisational reform. Whether by functional or political logic, today even short-term policies often depend on changes in current institutional processes. For instance, an increase in International Monetary Fund (IMF) reserves is widely linked to changes in IMF quotas. In slightly different ways, there is an apparent link between the implementation of domestic stimulus packages by national governments and their enthusiasm for the closing of tax havens and thus global, structural reforms.

\subsection{From the $G 8$ to the $G 20$}

The adjustment of global economic governance to new realities and the response to the financial crisis are thus intertwined. In early 2009 , the road to many if not all reforms seemed to pass by the G20. The April London summit became the effective focal point for policymakers and the public. It was billed to forge global cooperation on fiscal stimulus packages, chart a map for effective global and national financial market regulation and contain protectionism, as well as forge consensus on reform of the IFIs and new risk warning systems.

The, at least public, shift away from the G7/8 was maybe not surprising. Not only did it symbolically spread responsibility, global realities already undermined the G8's role and its perceived legitimacy. Recognition of this fact had previously resulted in a 'diffuse pattern of outreach' (Cooper 2007: 4) by the G8, as well as proposals for other variously enlarged global fora (see Evans 2007). The aim was variously to get those at the table that really count to assure legitimacy and effectiveness, but staying small enough to reach agreement.

The G8's combined economic strength was often enough for a decisive influence on markets or worldwide practice. Its power on most other systemic issues rested in the capacity to exercise leadership in competent fora or to provide 'multilateral sponsorship' (e.g. where consensus forged during G8 deliberation sustained initiatives within multilateral institutions where they had dominant weight).

The G20 is based on the somewhat vague notion of 'systemic importance', i.e. countries whose problems can become problems for the 'system' as a whole. Thus, membership expansion has a fundamentally stabilising purpose, despite its ostensible narrative of change. ${ }^{2}$

Moreover, before the crisis, the G20's role was minor. Its members saw it as a forum for informal and open dialogue contributing to 'better global governance'. Yet they also believed that G20 support for global initiatives had 'only a modest effect on members' behaviour and even less impact on the behaviour of non-member countries' (G20: 53). Moreover, enthusiasm for the grouping was lacking for some emerging countries, who at times preferred to secure their status as representatives of the developing world, to preserve their bargaining chips in future multilateral or bilateral negotiations in other ways, or who privileged other fora to connect to the G7 (Birdsall 2009; Yongding 2005; Beeson and Bell 2009).

If the G20 is to assume a major role and propel substantial change (of whatever sort), its authority will have to increase. Institutional authority has many potential sources: schematically, it can be based on (1) output and the ability to propel change and (2) the recognition of representativeness and, for global mechanisms, adherence to the principles of their constitution. Both of these factors depend in good part on the ability to forge a shared diagnosis (or a workable consensus) of the problem at hand. This will both underpin evaluation of the legitimacy of its membership as well as the ability to agree on policy and policy coordination. In recognition of this last point, the next section analyses the substantially different views of 'the problem at hand'.

\section{Crisis explanations and framing}

\subsection{Crisis frames}

Official policy documents often refer to the causes of the crisis as simply 'complex' and 'the culmination of years of economic and social policy choices' (e.g. IOSCO 2009: 6). Yet beyond this, large differences exist as to whom the blame is attributed to. Polled in early 2009, 72 per cent of Germans said that blame for the crisis lay outside their own country, compared with 39 per cent of British respondents and only 9 per cent of Americans. More interestingly maybe, Americans blamed their political leaders more than their bankers, with the British and Germans attributing almost equal proportions of 
blame to both (but Germany much less overall) (Kellner 2009: 29-31).

Alongside geopolitical weight and the measurable impact of the crisis, perceptions of origin and blame arguably influence leaders' views on reform and on participation and positioning in global fora. Various competing understandings or narratives of the crisis can be distinguished (see also Weber 2008):

1 The crisis is due to regulatory failure and its consequences in the main capitalist economies. On the one hand, this explanation highlights failures in domestic oversight of mortgage markets, rating agencies and banking supervision, notably with regard to credit underwriting standards and securitisation. On the other hand, it may also include psychological models and attention to internal incentive systems in the finance sector, which are seen to have engendered ever higher levels of internal risk taken by individually rational employees aiming to maximise their income. The latter approach and framing is reflected in a number of influential reports which provide analysis and advice on how to adjust individual-level incentives to provide macroeconomically workable outcomes (McKinsey 2008; IOSCO 2009).

2 The crisis is a major manifestation of the enduring 'stability-instability paradox' inherent in capitalist markets (Minsky 1986, 1992). Repeated and cyclical financial panics emerge from periods of stability and optimism where excessive risk taking becomes normalised, eventually leading to instability and crisis, and subsequent recovery. In this line of argument for instance, the history of past 'boom and bust' cycles includes instances ranging from the tulip crisis in 1637, to the Great

Depression and through to the Asian Financial Crisis and the dot-com bust. This view is directly espoused in a recent working paper of the Bank for International Settlements, which states 'the turmoil is best seen as a natural result of a prolonged period of generalised and aggressive risk-taking, which happened to have the sub-prime market at its epicentre ... it represents the archetypal example of financial instability with potentially serious macroeconomic consequences that follows the build-up of financial imbalances in good times' (Borio 2008).

3 The crisis is an expression of 'exploitative hegemony' in which the USA has acted as an irresponsible great power. Because it can force more of the costs of adjustment to shocks onto others it consistently exploits its position (Arrighi 2005). Some link this to the role and causes of global macroeconomic imbalances: 'Everyone agrees that it [the crisis] was caused by over-borrowing by Americans who were living beyond their means. But everyone continues to lend to the US because they don't know where else to put their money. Of course, the US is happy to keep on printing money if there are willing takers' (Rodrigues 2009). It is worth noting that the flipside of this debate paints the USA as a consumer at the mercy of Chinese (or Asian) trade and investment policies. ${ }^{3}$

4 The crisis marks a deep and fundamental catastrophe of Western financial capitalism, which originates in a systemic failure that was a fatal flaw in the US system, built on unquestioned trust in the self-regulating market and valuation of the profit motive. It was thus inevitable and ultimately un-repairable. This analysis positions itself at the most aggregate level and is often attributed to established antiglobalisation fora or radical economics. It found an unlikely echo in the pronouncements by Alan Greenspan in front of the House Government Oversight and Reform Committee who linked the financial crisis to a flaw in his 'governing ideology', notably assumptions about the nature of human behaviour in capitalist markets (New York Times 2008).

Of course, countries rarely adopt single narratives and neither do most individuals, at least not exclusively, but even differential adoption of their various ingredients informs often starkly different options for institutional responses. Different 'takes' on the crisis may be thought of as policy 'frames' (Schon and Rein 1994), which contain a number of explicit and implicit elements (Table 1), including:

1 A problem definition which contains information about which type of data or information is relevant and what information is to be relied on in an at least partially uncertain situation. 
Table 1 Narratives and frame components

\begin{tabular}{|c|c|c|c|c|}
\hline & Problem definition & Causal pathways & Remedies & 'Moral' judgement \\
\hline Regulatory failure & $\begin{array}{l}\text { Regulation (moral } \\
\text { hazard/adverse } \\
\text { selection) } \\
\text { Human behaviour } \\
\text { (individual) }\end{array}$ & $\begin{array}{l}\text { With right policies will } \\
\text { return to previous system } \\
\text { but with problem fixed }\end{array}$ & $\begin{array}{l}\text { Adjust individual } \\
\text { incentives. Financial } \\
\text { sector organisational } \\
\text { reform. National, if } \\
\text { necessary supranational } \\
\text { level. (Technical fix) }\end{array}$ & $\begin{array}{l}\text { Politicians to blame } \\
\text { for regulating wrong }\end{array}$ \\
\hline Cyclical crisis & $\begin{array}{l}\text { Asset bubbles/lack of } \\
\text { foresight } \\
\text { Human behaviour } \\
\text { (group) }\end{array}$ & $\begin{array}{l}\text { System will adjust itself. } \\
\text { Until next time }\end{array}$ & $\begin{array}{l}\text { Wait out and buffer } \\
\text { worst effects. } \\
\text { National level, via aid } \\
\text { (political decision) }\end{array}$ & Nobody to blame \\
\hline $\begin{array}{l}\text { Exploitative } \\
\text { hegemony }\end{array}$ & $\begin{array}{l}\text { Power differentials } \\
\text { and egotistical } \\
\text { behaviour (state) }\end{array}$ & $\begin{array}{l}\text { To prevent recurrence, } \\
\text { USA must be } \\
\text { permanently weakened }\end{array}$ & $\begin{array}{l}\text { Rebalance (i.e. Global } \\
\text { reserve currency, } \\
\text { pursuit of decoupling } \\
\text { as economic strategy). } \\
\text { National/regional }\end{array}$ & USA to blame \\
\hline Crisis of capitalism & $\begin{array}{l}\text { Wrong values/norms } \\
\text { Whole 'system' }\end{array}$ & $\begin{array}{l}\text { System change, } \\
\text { re-evaluation of growth } \\
\text { model, profit motive }\end{array}$ & $\begin{array}{l}\text { Alternative economic } \\
\text { organisation. 'moral } \\
\text { capitalism' All levels } \\
\text { (political) }\end{array}$ & $\begin{array}{l}\text { Principles of } \\
\text { capitalism (or its } \\
\text { 'variety') to blame }\end{array}$ \\
\hline
\end{tabular}

For the purpose of exposition, this table does not integrate the considerable debate on 'varieties of capitalism', which would be of relevance to a more fine-grained analysis (see Hall and Soskice 2001).

2 Definition of causal pathways which also structure future expectations. A broad example is the different answer to the question on whether or not the post-crisis world economy will differ fundamentally from the pre-crisis one. The answer looks very different if one adopted frames 4 and 2 above, whereas in the cases of 1 and 3 , it would depend on the nature of regulation or changing power relationships respectively.

3 Potential remedies. These provide the basis for different policy positions or priorities. An example may be the decision on prioritising a review of (financial) sector-wide incentive systems or the creation of a global reserve currency. More broadly, the above frames differ in putting the emphasis on technical or political dynamics, as well as with regard to the policy-level at which they should be addressed and on how much intervention is necessary.

4 A set of moral judgements. Linked to definitions of causality and selections of who the relevant actors are; frames attribute blame and thus shape relationships.

\subsection{Tracking national debates}

'Frames' help to account for long-lasting controversy even in the face of seemingly undisputed raw data. In turn, aligning policy proposals with more widely held frames provides a way to achieve consensus (as when responses to the crisis so far are widely perceived as a repudiation of 'free market discipline').

Between October 2008 and February 2009, a team of IDS researchers tracked such underlying frames in national debates in selected G20 countries: India, Japan, Indonesia, Mexico, Brazil, South Africa and South Korea, as well as following debates in Europe and the USA. The methodological approach was qualitative content analysis of web-based media and information resources and, in some cases, a limited number of target interviews with journalists and policymakers. The guiding questions involved the history of a given country's engagement with the G20/G8, the nature of the domestic debate on the origins of the crisis and who was to blame/seen to provide the solution, with special attention paid to international approaches to dealing with the global financial crisis. 
The general aim was to identify elite-level debates. In contrast to government statements, they are less likely to be influenced by the attempt to send signals to nervous markets. Yet they neither represent government positions or general public opinion.

Based on frequency and source, researchers forged qualitative judgement on the importance of the different views expressed (the focus on web-based media meant that national-level and bigger/more widely distributed outlets were privileged). Not unsurprisingly, elements of all of the above narratives were variously expressed in various national media, albeit unequally and only the main themes are indicated below. At times the specific nature of the media market in a given country was taken into account. For instance, in South Korea, researchers also conducted a series of semi-structured phoneinterviews. However, it is important to underline that these findings are indicative, not representative and purely concern national debate at the elite-level.

Further caveats include that during the exercise, a drastic shift occurred in various countries away from a view that they would remain relatively unharmed, to a much more alarmed perspective. This was particularly raised by researchers working on Japan and Mexico. This and the often wide range of views expressed within single countries underlined that definitions and explanations of the crisis were not yet fixed. Data may also be affected by adjacent election periods in Canada, South Africa and India as well as the visit of US Secretary of State Hillary Glinton to South Korea (February 2009). The next two sections present findings grouped into two thematic sub-sections. The first pertains to crisis explanations (causal pathways and problem definition), the second focuses on attitudes surrounding potential remedies or institutional arrangements.

\section{Explanations of the crisis}

Not surprisingly, in countries without a homegrown banking crisis, interdependence was seen as a cause of the crisis. However, this occurred both in the simple sense of behaviour 'there' affecting behaviour 'here', as well as in the further sense in which the crisis itself was the product of a specific form of interdependence or relationship. The latter perspective was sometimes framed in terms of a culture clash, an 'unhealthy relationship' between Asia and the West (e.g. in India, South Korea, Indonesia). Here, the term 'unhealthy relationship' is a direct quote from the speech of L.K. Advani, leader of the parliamentary opposition in India and prime ministerial candidate of the Bharatiya Janata Party (BJP) who in the documented speech went on to juxtapose the 'excesses' of the western world to so-called 'Asian frugality' (Advani 2008). Such a theme, encapsulated in notions of Western 'greed' and arrogance emerged from reviews in other countries as well. As such, the editor of the South Korean Newspaper, Joong Ang Ilbo, referred to the fact that the USA would have to abandon its 'arrogant attitude' and blamed the 'invisible hand of greed and deception' (Kim Chong-hyuk 2008). In Indonesia this view also seemed widespread with references being made to the causes of the economic crisis in the insatiable pursuit of profit and greed by big market players, lack of government regulations, and powerthirsty and corrupt government bureaucrats in the United States, Europe, Japan and other capitalist countries' (Guharoy 2008).

In Brazil, the report indicated a general irresponsibility of western capitalist economies functioning in an irresponsible way due to lack of appropriate control and regulation of financial agents (Moreira 2009). In Mexico, the Archdiocese of Mexico declared in its weekly newspaper that the crisis presented the failure of 'savage, speculative capitalism'(La Botz 2009).

The issue of alleged Chinese currency manipulation emerged as a topic of debate in the USA following the remarks of the Secretary of the Treasury, Timothy Geithner, on the subject, and was also echoed in some editorials in the UK. They did not appear in any of the other G20 countries. In China, where there has been little public pronouncement, evidence gleaned from informal conversations suggest that Chinese experts and academics clearly put the blame on American capitalism and spending habits.

In continental Europe, French President Sarkozy's speech in Paris in January was widely noted for his attack on 'immoral capitalism' where he put the blame on financial speculators in particular. ${ }^{4}$ The speech delivered by UK Prime Minister, Gordon Brown, at St Paul's Cathedral 
the day before the G20 summit also emphasised the moral dimension of any sustainable capitalist system (Brown 2009).

In contrast, in Canada the initial reaction appears to have interpreted the crisis as a foreseeable regulatory failure. Notably, Stephen Harper during his election campaign said simply that 'a lot of things have gone wrong here and, by the way, there were a lot of warning signs. This should not be a huge surprise' (Argitis 2008).

These competing views also relate to stances on participation and positioning in global fora. Many developing country experts seem to prefer a global rather than a national approach to the crisis (Coupé 2009). One global public opinion survey seemingly indicated major support for (unspecified) 'fundamental changes', both in national and international economic systems (68 and 70 per cent, respectively) (BBC 2009). More differentiated, the Eurobarometer surveys (2009) indicate large variation among the EU members states' public.

In our tracking exercise, distrust in current highlevel processes seemed widespread. Again, dominant themes are listed below.

\section{From explanation to institutional arrangements}

Researchers observed wariness of G20 symbolism or other non-substantive incorporation in international fora, which were however considered important for information gathering. In Japan, observers noted the relative lack of concrete outcomes of the G20 summit in Washington (Yamazaki 2008), but also indicated its signalling factor both in terms of revealing the declining role of the USA as well as publicising a 'clear conflict of interests between the US and the EU' (Makabe 2008).

In India, distrust of the reasons behind current initiatives was articulated in this way: 'A new global structure is slowly and painfully falling into place, not because of any voluntary reform, some altruistic new vision, but for financial and political survival' (Guharoy 2008).

Research tracked much open and latent distrust of the role of the IMF in any solution, linked to seemingly widespread concerns that its 'ideology' has not changed (India, Japan, Indonesia, Mexico). In South Africa, President Motlanthe has publicly declared that reforms at the summit to strengthen the IMF and the World Bank would have to be accompanied by representation for Africa in the international financial system. The general media has been even more critical (e.g. Diakanyo 2008).

Past experience of the Asian crisis was depicted as a resource of technical knowledge and a source of distrust. In Korea, the president's economic team was replaced to include those with policy experience from the 1997-8 Asian crisis (Economist Intelligence Unit 2009). In Indonesia, researchers found resentment of western institutions, notably the IMF, for the treatment received during the Asian crisis of 1997-9.

Reports from Japan and China saw no return to the pre-crisis status quo. In Japan, this linked to the possibility and/or necessity to move away from an export-based growth model (Makabe 2008). Indian sources also held the view that the existing global order had run its course. ${ }^{5}$ On the other hand, economic commentators pointed to the lack of alternatives suggested by developing countries 'beyond suggesting higher IMF quotas' (Anklesaria Aiyar 2009a,b) and voiced considerable scepticism regarding real change: 'most likely those who brought the global economy to its current pass will masquerade as its rescuers, and the interests of the creditors will be protected by Washington' (Guha 2008).

Wariness of G20 symbolism was expressed by a number of interlocutors in South Korea. At the extreme end it was seen as a mechanism to make others share in the clean-up of the 'mess' created by the G7. The view that the G20 itself was mainly valued for the purpose of information gathering or diplomatic reasons was expressed in both India (Mattoo and Subramaniam 2008) and South Africa (Draper 2008, 2009). On the other hand, the recurrent emphasis on 'seizing' this opportunity and shaping the agenda instead of letting it be shaped by the G7 reflected more ambivalence. ${ }^{6}$ A particular element was unsurprisingly the willingness to use the G20 to engage with new US leadership and reinforce multilateralism more broadly. This was a particular theme in Brazil (President Lula was the 2008 chair of the G20), as well as in South Korea and Indonesia, where it appeared linked to the Secretary of State, Hillary Clinton's visit. 
- IMF reinforced through increased resources and announcement of an enhanced future role in the supervision of global macroeconomic policies. Most of the monetary reinforcement was left unspecified or stemmed from previous pledges (Giles 2009). No commitment to further changes to the quota system; instead already agreed-upon governing reforms were pushed forward in time. In this sense, no change was made which is likely to address the distrust of the institution which emerged from the frames above. $^{8}$

- Regional Multilateral Development Banks strengthened by pledges of $\$ 100$ billion to be raised from international capital markets. The World Bank received only pledge of support through unspecified and 'voluntary' bilateral contributions.

- UN left empty-handed: 'called upon' to monitor the impact of the crisis on 'the poorest and most vulnerable' (Final Communiqué, para. 25); the long-standing proposal of the creation of a UN-based World Economic Council was revived by the German Chancellor Angela Merkel but had no follow-up.

- Vague commitment to reviving the Doha round trade negotiations within the WTO framework and an anti-protectionist statement (for a useful analysis, see Baldin 2009).

- Macroeconomic imbalances not directly/publicly addressed. ${ }^{9}$

- Details of future supervisory powers of IMF and enlarged Financial Stability Forum (now Financial Stability Board) left to be defined, including precise nature of an early warning system. Announcements were made with regard to future regulation of systemically important hedge funds, recruitment and numeration practices, money laundering and tax evasion.

- Efforts to deal with 'toxic assets' left to national governments.

No further fiscal stimulus was agreed, due largely to French and German resistance.

In Indonesia, the G20 was notably presented as a 'bridge' (alongside the Chiang Mai Initiative and the East Asia summit) through which Indonesia could strengthen cooperation of the East Asian region with the USA (Wanandi 2009). ${ }^{7}$ The theme of regionalism was also apparent in Brazil, where it linked to the government's attention to the Mercosur market as a regional base and the concern to retain free trade within it.

An interesting element given the preceding discussion was the insistence that Asian financial reserves provide an important source of power not easily traded off. As an article in the Jakarta Post argued: '[Indonesia] needs to discourage its other fellow members of the G20 from signing up to a new global structure that the World Bank's Robert Zoellick is suddenly promising with such enthusiasm, unless it has real checks and balances. The collective bargaining power of the G20's $\$ 7$ trillion in reserves should not be wasted at this critical juncture' (Jakarta Post, 30 September 2008). The related debate about an eventual replacement of the dollar as the de facto global currency with special drawing rights had not begun during the time monitored by the researchers, who did however record the public awareness by Japanese commentators raising the issue that the value of the dollar is 'outstanding' (e.g. Tsuda in Japan Mail Media 2008).

\section{Implications}

This article linked issues of institutional capacity and reform to issues of policy framing. This was based on the assumption that the purposes of different institutional arrangements will be shaped by different views on what needs fixing, Does the above help make sense of what happened 
at the London Summit and, more interestingly, what happens now? Indeed, some of the themes raised in our tracking were later echoed in official country statements at the UN or the London Summit itself (Muchhala 2009; Bretton Woods Project 2009). However, policy positions are the result of institutional and political dynamics where geopolitical weight and domestic debates are only two of many factors. Rather than using our tracking exercise to predict country-positions or specific outcomes at the summit, we therefore use the information provided to reflect on its outcomes and their future.

Looking at our data, it would be a surprise if anything happened in London. Debates depict not just large diversity, but also high degrees of distrust and blame, albeit alongside some opening, particularly with regard to the new US leadership. The diversity of framing suggests that any results would reflect hard bargaining or 'soft' symbolic politics rather than technical problem solving (which problem needs solving, after all?).

What then, was the record of the summit? Most concrete measures dealt with solving the crisis and took the form of monetary announcements. Most announcements involving future crisis prevention and structural change took the form of agreements to agree (on details in the future).

The results of the summit should not surprise: (1) Structural change is highly difficult as actors give away future power not punctual (one-off) benefits. (2) Any outcomes were achieved in a highly divided world, which, as the above discussion shows, was probably more divided rather than more united by the interdependence demonstrated through the crisis. (3) Policy was debated in an environment marked by high degrees of uncertainty, both with regards to the dynamics of the crisis and the preferences of the actors. ${ }^{10}$

Different frames make precise summit agreements less likely, but they probably matter even more for understanding the likelihood of long-term implementation and regulation. They unveil some of the sentiments behind the politics of international summits and provide useful hints for the practical future of their outcomes.

Important decisions are still outstanding; expert fora are working at defining the detail of any change, but uncertainty about data and causality remains high. In this situation trust is a more crucial and more scarce resource than normal, arguably analogous to a necessary 'credit-flow' in the system of international institution building. Where does this particularly matter? For once, future supervisory institutions charged with identifying and isolating 'systemic risk' in global financial markets (the IMF and the Financial Stability Forum, FSF) will face the significant problems of its ex ante identification. Given the current inability to quantify or definitely assess risk factors, supervisory institutions will need a considerable degree of goodwill among participating countries, so that not only firsthand information is provided but any ultimately proposed measures are actually implemented. This analysis suggests at the very least, that much continuous outreach and consensusbuilding needs to be done.

What happens in the absence of consensus but in the presence of relative independence? Scenarios range from 'global disengagement', where developing and developed countries alike concentrate on domestic policy issues to the detriment of any type of international cooperation and may focus on import substitution, domestic demand and raise protectionist barriers, to a new focus on regional grouping and trading links or, as a scenario, a wholly new reconfiguration, with power shifting to newly engaged developing nations (Rodrik 2009).

As noted, the promotion of less outward oriented developing strategies was raised in Japan and also, vocally, by the communist party in India. The theme of regional concentration was also evident in some cases (e.g. Indonesia and Brazil). The European Union is arguably providing an example for successful attempts to reach a degree of regional regulation and response. If not addressed globally, countries are addressing the question of macroeconomic balances through routing strategies, as China does with increasing recourse to gold. ${ }^{11}$

In sum, the withdrawal from global arrangements may be one of the biggest threats to success in a collective crisis response, unless the variety of different views are addressed head-on. Our methodological approach, while largely suggestive in this article, provides one possibility by which to uncover the debates, openings and tensions behind summits and beyond diplomatic agreements. 
Lastly, any pre-designed approach in which those to blame for the crisis are seen as devising its solution for others to implement, are unlikely to be successful, adding onto a similar situation the wider international community is already facing in its efforts to combat and mitigate climate change.

Here, just expanding representation is not a solution. Policymakers would be well advised to track and understand the narratives of the G20 and wider groups of developing nations as well as the institutional and political pathways by which they influence reform options. Commitments

\section{Notes}

1 The G20 includes the G7 + European Union, the World Bank and the International Monetary Fund, Argentina, Australia, Brazil, China, India, Mexico, Russia, Saudi Arabia, South Africa, South Korea, Turkey and Indonesia. It existed, since 1999, at the level of finance ministers and only met at the level of heads of state in November 2008. At the London Summit, additional actors were present, including the Netherlands, Spain, representatives of NEPAD, ASEAN, the WTO, the Financial Stability Forum and the UN Secretary General Ban Ki-moon.

2 Indeed, as documented in its own (commissioned) history (G20 n.d.), the aim of the initial G20 was to create the consensus for Bretton Woods' initiatives and provide support for globalisation after the Asian crisis.

3 See the very different take of a recent editorial in the Financial Times which instead blames Asian savings for the resulting troubles: 'Countries with reserve currencies and surpluses ... have an exceptional obligation ... since they rely so heavily on the spending and borrowing of others for their own macroeconomic stability. China may be beginning to understand this' (Financial Times 2009). Gourinchas and Rey (2005) estimate that a 10 per cent depreciation of the dollar represents, all things equal, a transfer of 5 per cent GDP from the rest of the world (quoted in HM Treasury 2009).

4 More precisely, Sarkozy, speaking at the symposium 'New World, New Capitalism' on 8 January 2008 blamed financial speculators for having 'perverted the logic of capitalism'.

5 For example Prakash Karat, General Secretary of the Communist Party of India, www.hindu.com/2008/12/15/stories/ made at international summits are themselves only one influence on ultimate policymaking, which takes place on multiple levels and frequently depends on domestic politics that provide support and open channels of implementation.

For policymakers, this points to the importance of forms of interaction. These include formal meetings and institutions but also the less visible fora where trust and credibility can be restored or established. Both are crucial to reach a workable consensus.

2008121554201300.htm (15 December 2008 and 21 February 2009).

6 Interviews South Korea. Cho Yoon-Je, professor of economics at the Graduate School of International Studies, Sogang University (Interview). Chosun Daily in-house columnist Kim Ki-cheon.

7 Even though not tracked in the media reports, it is noteworthy that in early March, South Korea began formal talks with Australia and New Zealand on bilateral free trade agreements and made overtures to the ASEAN.

8 A commitment was renewed to base the recruitment of heads of international organisations on merit rather than on nationality.

9 Indirectly, the introduction of IMF flexible credit lines may reduce governments' incentives to self-insure against instability by accumulating foreign currency reserves. Also, future increased global supervision by the IMF may include relevant macroeconomic policies.

10 A subsequent report by one of the agencies charged with hammering out the details of regulatory reform said what summit leaders would never say: 'Regulators are cognisant that the causes and consequences of the crisis are still unfolding, and it is perhaps too early to formulate a concrete agenda of global regulatory reform' (IOSCO 2009).

11 Even though the Russian lending to Iceland may not be highly significant, China concluded a loan agreement with Brazil in early March 2009 extending credit of US $\$ 1.5$ billion to the Central Bank of over a period of three years. This was followed by a currency swap arrangement with Argentina in late March 2009, unprecedented in the Latin Hemisphere (Wang 2009). 


\section{References}

Advani, L.K. (2008) Speech at the Hindustan Times Leadership Summit, 21 November, http://offstumped.nationalinterest.in/2008/11/ 21/lk-advanis-speech-at-ht-leadership-summit (accessed 13 May 2009)

Anklesaria Aiyar, Swaminathan S. (2009a) Times of India, 18 January

Anklesaria Aiyar, Swaminathan S. (2009b) Times of India, 15 February

Argitis, T. (2008) Canada's Harper Says Financial Crisis Caused by U.S. Policies, Bloomberg News Service, www.bloomberg.com/apps/ news?pid $=20601082 \&$ refer $=$ canada $\&$ sid $=$ akX5_CUZ1tig (accessed 14 May 2009)

Arrighi, Giovanni (2005) 'Global Governance and Hegemony in the Modern World System', in Alice D. Ba and Matthew Hoffman (eds), Contending Perspectives in Global Governance: Coherence, Contestation and World Order, London: Taylor and Francis

Baldin, R. (2009) Trade and the London Summit Outcome, www.voxeu.org/index.php?q= node/ 3417 (accessed 14 May 2009)

BBC World Service (2009) Economic System Needs 'Major Changes': Global Poll, March 2009, www.worldpublicopinion.org/pipa/pdf/mar09/ BBCEcon_Mar09_rpt.pdf (accessed 14 May 2009)

Beeson, M. and Bell, S. (2009) 'The G-20 and International Economic Governance: Hegemony, Collectivism, or Both?', Global Governance 15: 67-86

Birdsall, N. (2009) Comment on Dani Rodrik's piece, 29 January, http://voxeu.org/index .php?q= node/2888 (accessed 14 May 2009)

Borio, C. (2008) The Financial Turmoil of 2007-?: A Preliminary Assessment and Some Policy Considerations, BIS Working Papers 251, March, www.bis.org/publ/work251.htm (accessed 13 May 2009)

Bretton Woods Project (2009) Country Positions for the London Summit, 1 April, www.brettonwoodsproject.org/art-563944 (accessed 13 May 2009)

Brown, G. (2009) Speech and Q\&A, at St. Paul's Cathedral, 31 March, www.number10.gov.uk/ Page 18858 (accessed 14 May 2009)

Cook, S. and Lam, W. (2009) The Financial Crisis and China: What are the Implications for Low Income Countries?, Brighton: IDS, www.ids.ac.uk/download.cfm?objectid $=$ C3781 CCA-992B-30CA-0D2DBE1CAF 139241 (accessed 14 May 2009)
Cooper, Andrew F. (2007) The Logic of the BRICSAM Model for G8 Reform, Policy Brief in International Governance 1, May, CIGI Policy Brief at www.cigionline.org

Coupé, Tom (2009) Developing-nation Economists' View of the Crisis: GDN 2009 Survey, www.gdnet.org/CMS/getFile.php?id = gdn_ 2009_survey_results (accessed 14 May 2009)

Diakanyo, S. (2008) 'The Global Financial Crisis and the Suspicious IMF Intervention' on Thoughtleader (Mail and Guardian blog), www.thoughtleader.co.za/sentletsediakanyo/ 2008/10/27/the-global-financial-crisis-and-thesuspicious-imf-intervention (accessed 3 July 2009)

Draper, P. (2009) 'The Financial Crisis and G20 Summitry: Decoding (South) African Positions', a workshop hosted by the South African Institute of International Affairs, Review of Proceedings', 5 March, www.fes.de/cotonou/DocumentsEN/Thematic Focus/Aid/FinancialCrisis_DecodingAfricanPo sitions.pdf (accessed 14 May 2009)

Draper, P. (2008) Africa: How South Africa Should Handle G20 Summit, 14 November, http://allafrica.com/stories/200811140221.html (accessed 3 July 2009)

Economist Intelligence Unit (2009) Country Report: South Korea, February

Eurobarometer (2009) Europeans and the Economic Crisis, report and data, March, www.ec.europa.eu/ public_opinion (accessed 14 May 2009)

Evans, A. (2007) A New Global Leaders' Forum? Comparing and Evaluating Recent Proposals, New York: Centre on International Cooperation Policy Paper, Global Risks Program, New York University, www.cic.nyu.edu/international security/docs/newgloballeadersforum.pdf (accessed 13 May 2009)

Financial Times (2009) 'What the G20 Has to Do in London', 29 March

G20 (n.d.) 'The Group of Twenty, A History', www.g20.org/Documents/history_report_dm 1 . pdf (accessed 14 May 2009)

G20 (2009) London Summit Final Communiqué, www.londonsummit.gov.uk/resources/en/PDF/ final-communique (accessed 14 May 2009)

Giles, C. (2009) 'Large Numbers Serve to Hide Big Divisions', Financial Times, 3 April

Gourinchas, P.O. and Rey, H. (2005) 'From World Banker to World Venture Capitalist: U.S. External Adjustment and the Exorbitant Privilege', NBER Chapters 0121, Cambridge MA: National Bureau of Economic Research, 
http://ideas.repec.org/h/nbr/nberch/0121.html (accessed 14 May 2009)

Guha, S. (2008) Will the G-20 Supplant the G-8?, 19 November, UPI Asia, www.upiasia.com/ Economics/2008/11/19/will_the_g20_supplant the_g8/5015 (accessed 14 May 2009)

Guharoy, Debnath (2008) 'If the People Now Own Major Banks, Who are their Board Members?', Jakarta Post, 14 October, www.roymorgan.com/documents/indArticles/ the_jakarta_post_article_99.pdf

Hall, P. and Soskice, D. (eds) (2001) Varieties of Capitalism, Oxford: Oxford University Press

HM Treasury (2009) Global Economy Note: Untangling the Global Economy, London: HM Treasury

IMF International Monetary Fund (2009) Global Economic Policies and Prospects, note by the Staff of the International Monetary Fund for the Group of Twenty Meeting of the Ministers and Central Bank Governors, 13-14 March, London

International Organization of Securities Commissions (IOSCO) (2009) Unregulated Financial Markets and Products, Consultation Report of the Technical Committee, May, Madrid

Japan Mail Media (29 Sep 2008) 'Answers to Ryu Murakami from experts in Economics and Finance, Q.930' http://ryumurakami.jmm .co.jp/dynamic/economy/article515_10.html (accessed 3 July 2009)

Kellner, P. (2009) 'Pessimists but not Extremists', E-sharp, May-June, www.esharp.eu/issue/ 2009-3/Pessimists-but-not-extremists (accessed 13 May 2009)

Kim Chong-hyuk (2008) 'Outlook: Economy in Peril', Joong Ang Ilbo, 27 October, http://joongangdaily.joins.com/article/ view.asp?aid=2896556 (accessed 13 May 2009)

La Botz, D. (2009) 'Financial Crisis Hits Mexico: Social Grisis on the Horizon?', Monthly Review, http://mrzine.monthlyreview.org/ labotz081008.html (accessed 10 May 2009)

Makabe, A. (2008) 'Answers to Ryu Murakami from Experts in Economics and Finance, Q.938',Japan Mail Media, 24 November, http://ryumurakami.jmm.co.jp/dynamic/ economy/article524_1.html (accessed 14 May 2009)

Mattoo, Aaditya and Subramaniam, Arvind (2008) Economic and Political Weekly, 8 November

McKinsey \& Company (2008) The Future of U.S. Financial Regulation and its Implication, 15 December
Minsky, H.P. (1992) The Financial Instability Hypothesis, Working Paper 74, Annandale-onHudson, New York: The Jerome Levy Economics Institute of Bard College, www.levy.org/visit.aspx (accessed 14 May 2009)

Minsky, H.P. (1986) Stabilizing an Unstable Economy, Yale: Yale University Press

Moreira, Assis (2009) A Aposta do Brasil no G-20 Financeiro, Report for Government of Brazil, www.mre.gov.br/portugues/noticiario/nacional /selecao_detalhe3.asp?ID_RESENHA= 546379 (in Portuguese) (accessed 14 May 2009)

Muchhala, B. (2009) Delegations Respond to Commission's Crisis Proposals, 1 April, www.ifiwatchnet.org/?q=en/node/3 1699 (accessed 13 May 2009)

New York Times (2008) 'Greenspan Concedes Error on Regulation', 31 October, www.nytimes.com/2008/10/24/business/econo my/24panel.html?hp (accessed 13 May 2009)

Rodrigues, Francisco (2009) 'Development and the Crisis'-A Critical Reading, 23 February, www.voxeu.org/index.php?q = node/3121 (accessed 14 May 2009)

Rodrik, Dani (2009) Let Developing Nations Rule, 28 January, www.voxeu.org/index.php?q= node/ 2885 (accessed 14 May 2009)

Schon, D.A. and Rein, M. (1994) Frame Reflection: Toward the Resolution of Intractable Policy Controversies, New York: Basic Books

Wanandi, Jusuf (2009) 'Insight: President Obama and Indonesia-United States Relations', Jakarta Post, 21 January

Wang, Tina (2009) China Touts Yuan to Emerging Economies, Forbes.com, 31 March, www.ft.com/cms/s/0/b6b2fc8a-1812-11de-8c9d0000779fd2ac.html (accessed 6 May 2009)

Weber, Steve (2008) The Geopolitics of the Financial Crisis, talk manuscript, Berkeley: Institute for International Studies, University of California

Yamazaki, H. (2008) 'Answers to Ryu Murakami from experts in Economics and Finance, Q.938',Japan Mail Media, 24 November, http://ryumurakami.jmm.co.jp/dynamic/ economy/article524_7.html (accessed 14 May 2009)

Yongding, Yu (2005) 'China's Evolving Global View', in John English, Ramesh Thakur and Andrew F. Cooper (eds), Reforming from the Top: A Leaders' 20 Summit, Tokyo: United Nations University Press: 187-200 